\title{
Effect of socioeconomic status disparity on child language and neural outcome: how early is early?
}

\author{
Hallam Hurt ${ }^{1,2}$ and Laura M. Betancourt ${ }^{1}$
}

It is not news that poverty adversely affects child outcome. The literature is replete with reports of deleterious effects on developmental outcome, cognitive function, and school performance in children and youth. Causative factors include poor nutrition, exposure to toxins, inadequate parenting, lack of cognitive stimulation, unstable social support, genetics, and toxic environments. Less is known regarding how early in life adverse effects may be detected. This review proposes to elucidate "how early is early"through discussion of seminal articles related to the effect of socioeconomic status on language outcome and a discussion of the emerging literature on effects of socioeconomic status disparity on brain structure in very young children. Given the young ages at which such outcomes are detected, the critical need for early targeted interventions for our youngest is underscored. Further, the fiscal reasonableness of initiating quality interventions supports these initiatives. As early life adversity produces lasting and deleterious effects on developmental outcome and brain structure, increased focus on programs and policies directed to reducing the impact of socioeconomic disparities is essential.

$\mathrm{t}$ is not news that poverty adversely affects child outcome. The literature is replete with reports of deleterious effects on developmental outcome, cognitive function, and school performance in young children (1-12). Factors implicated as causative agents include poor nutrition, exposure to toxins, inadequate parenting, lack of cognitive stimulation, unstable social support, and genetics (13-18). Recently, there has been emphasis on toxic stress experienced by children resulting from events such as exposure to violence, child abuse, or severe maternal depression. Drawing from these multiple influences on outcome, Shonkoff et al. (19) have described an ecobiodevelopmental model in which early life experiences and environment may affect brain structure and function $(20,21)$. Specifically, stressful experiences have been associated with the size of the amygdala, hippocampus, and prefrontal cortex and with functional differences in learning, memory, and executive functioning $(19,22)$. These findings are consistent with the concept of biological embedding of adversity $(23,24)$. Supportive evidence for this concept primarily emanates from research in children and youth, with few studies in infants and toddlers. Given that such effects may be present at these younger ages, current efforts to intervene may be too late, after development of foundational aspects of cognitive function has been established.

To elucidate "how early is early," we review a growing literature describing the young ages, toddlerhood, and even infancy, at which effects of poverty can be detected. To set the scene, in particular for readers without firsthand experience with children from socioeconomically challenging circumstances, we first describe our decades-long investigative endeavor that revealed the pervasive effects of poverty on poor inner-city children, and the young ages at which effects were detected. We follow with a review of seminal work regarding the consequences of poverty on language performance in very young children. We chose to discuss effects on language specifically as the association between language and low socioeconomic status (SES) appears stronger than for other neurocognitive systems $(4,5)$. Moreover, language function is strongly associated with academic achievement (25). Subsequent to this, we discuss the emerging literature on neural effects of poverty. A caveat for this review: while "poverty" is not always synonymous with low SES (a multidimensional construct typically defined by income, insurance status, education, and/or job category), differentiating between the two for each investigation described is beyond the scope of this discussion. Thus, for purposes of this review, the terms poverty and low SES often will be used interchangeably.

\section{EXPLORING THE EFFECT OF GESTATIONAL COCAINE EXPOSURE ON CHILD OUTCOME: A CAUTIONARY TALE}

In 1989, faced with the crack cocaine epidemic sweeping America, our group of investigators initiated a study designed to evaluate the effects of gestational cocaine exposure on infant and child outcome. Given the early reports of devastating effects in children, we anticipated finding robust differences between exposed and nonexposed children at a young age. Between 1989 and 1992, we enrolled 224 subjects, primarily African American, half of whom had gestational cocaine exposure and half of whom did not. All mothers were of low SES as indicated by their receipt of medical assistance at the time of

'Division of Neonatology, The Children's Hospital of Philadelphia, Philadelphia, Pennsylvania; ${ }^{2}$ The Perelman School of Medicine, University of Pennsylvania, Philadelphia, Pennsylvania. Correspondence: Hallam Hurt (hurt@email.chop.edu)

Received 17 April 2015; accepted 23 August 2015; advance online publication 16 December 2015. doi:10.1038/pr.2015.202 
delivery. To be eligible, mothers admitted to cocaine use during at least two trimesters of pregnancy. Nonusing mothers had a negative history for cocaine use as well as negative urine drug screens on mother and baby at time of delivery. Eligibility for infants included gestational age $\geq 34 \mathrm{wk}$, Apgar $>8$ at $5 \mathrm{~min}$, and no conditions associated with developmental delay. In the ensuing years from 1989 to 2014, numerous evaluations were conducted on an every 6-12 mo basis by examiners masked to subject exposure status (26-39). Here, we focus on results from evaluations of cognitive function conducted in subjects at young ages.

\section{IQ at Age 4 y}

At age $4 \mathrm{y}, 71$ children with gestational cocaine exposure and 78 nonexposed were evaluated. Results showed that the exposed and nonexposed groups did not differ on mean Full Scale IQ (FSIQ), 79.0 vs. 81.9 ( $P=0.13$ (values for cocaineexposed children given first)). Although cocaine-exposed and nonexposed groups did not differ in FSIQ, 93\% of the cocaineexposed and $96 \%$ of the control children had FSIQ scores below 100 (29), the standardized mean score for the test (40). Thus, while FSIQ scores did not differ between cocaine-exposed and nonexposed children in this inner-city cohort, the unsettling conclusion was that both groups were performing well below the test norm of 100 (average range: 90-110). This finding led to two new questions: (i) what factors were associated with those children, regardless of exposure status, who performed at or above average range for the FSIQ and (ii) in reexamination of assessments conducted at younger ages, was an earlier divergence of our cohort from normative samples detectable? In regard to the first question, 118 of the children (exposed and nonexposed taken together) had FSIQs below average and 32 had FSIQs in the average range or above. The two groups did not differ in prenatal or natal characteristics (all $P>0.18$ ). The children with average or above average FSIQ did, however, have more developmentally appropriate caregiver interactions and higher scores on the Home Observation Measurement of the Environment than the children with below average FSIQ. For example, children with more enriching home environments were more likely to have at least 10 books in the home, to have toys and puzzles that taught colors and shapes, to have experienced greater warmth and affection from their caregiver, and to have been on a trip to a museum within the past year. In conclusion, potentially malleable environmental factors (parenting and home environment) were more influential on FSIQ than gestational exposure to cocaine in these "inner-city achievers" (41,42).

\section{Developmental Outcome at Ages 6-24 mo}

In regard to the second question, indeed, a divergence of our cohort from test norms was detectable at ages earlier than $4 \mathrm{y}$. Results from the Bayley Scales of Infant Development II, conducted at ages 6 through $30 \mathrm{mo}$, showed that cocaine-exposed and nonexposed children did not differ on the Mental Developmental Index $(P \geq 0.16)$; however, both groups' scores were $\sim 1$ SD below the mean standard score for the test

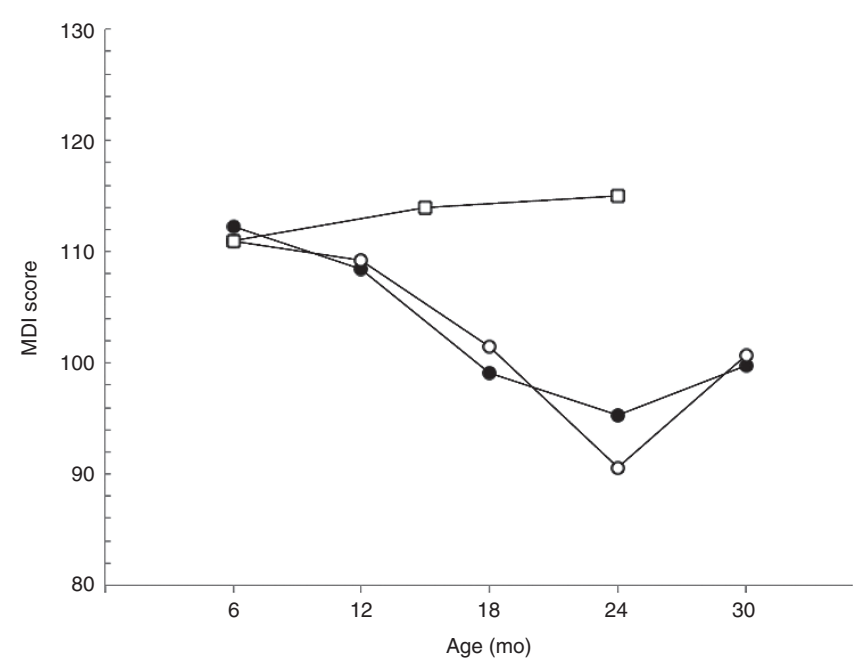

Figure 1. Bayley Scales of Infant Development - Second Edition (BSID-II) MDI scores of cocaine-exposed ( ) and nonexposed (O) children at 6-, 12-, 18-, 24-, and 30-month follow-up visits. By repeated-measures ANOVA, group effect, $P=0.94$; time effect, $P<0.001$; and group by time interaction, $P=0.34$. Middle-class external comparison group $(\square)$ is composed of full-term, primarily white, privately insured children. Divergence of scores for low-socioeconomic status groups and middle-class comparison group begins at age $12 \mathrm{mo}$. Reprinted with permission from ref. 26. MDI, Mental Development Index.

$($ mean $=100, \mathrm{SD}=15)$ derived from a normative sample of children. To further explore this divergence, we compared scores from our cohort with external data obtained from a middle-class cohort of children assessed at similar ages who were part of a project conducted elsewhere, by other investigators, and at a different time (43). Results of this comparison showed both the exposed and nonexposed groups in our cohort were performing less well than the external cohort of middle SES children (Figure 1) (26).

For years our focus had been the lack of difference in outcome between cocaine-exposed and nonexposed groups. In retrospect, an equally compelling finding was the early divergence of scores of a poor inner-city cohort from both a normative sample and an external middle-class group, beginning at $\sim 12$ mo of age (26). Thus, conclusions were twofold: children of low SES, with and without gestational cocaine exposure, had similar performance in multiple outcome measures; however, both groups were performing poorly. This unanticipated but troubling finding prompted our current quest to better understand effects of poverty, and timing of such effects, specifically on language outcome and brain structure, in very young children.

\section{POVERTY AND LANGUAGE FUNCTION}

As described earlier, we have chosen to focus on SES effects on language at young ages as "language is one of the most powerful symbolic systems through which children learn to understand and interpret their physical, social, and conceptual worlds" (44). In turn, these language skills, strongly associated with academic success, are known to differ by SES, with lower SES children performing less well than higher SES (4-6,44-49). 


\section{Review $\mid$ Hurt and Betancourt}

The importance of language competency is further described by Burchinal, who writes "Language skills not only provide the underpinning for acquisition of academic and behavior skills for all children, but they also apparently account, in part, for why children exposed to social risk are more likely to struggle academically" (48). Among numerous investigations of SES effects on language development, we have selected several studies demonstrating the earliest time points at which such differences have been detected.

\section{Language Outcome at Age $3 \mathrm{y}$}

Arguably the most well-known investigation regarding SES and language outcome is seminal work by Hart and Risley $(50,51)$. These investigators enrolled 42 families, 13 of upper or professional class, 10 middle class, 13 working class, and 6 on welfare. Over the next $2 \frac{1}{2}$ y, observers recorded monthly visits in the home of each family. Transcripts of these encounters were coded to include designating words spoken into categories of "encouragements," such as praise, and "discouragements" or negative reinforcement. At the end of the 3-y study, the investigators found that in the more affluent homes, the average number of words heard by a child in an hour was 2,153 , whereas among the working-class families, it was 616 . Moreover, by age 3 y, 500,000 encouragements were heard in professional homes in comparison with 75,000 in welfare homes. The reverse was true for discouragements, with 80,000 heard in the affluent homes vs. 200,000 in the lower SES homes. At age 3, the average Verbal IQ was 117 in the higher SES children compared with 79 in those from more challenging environments. By age 4 , the investigators calculated that children from wealthier families had heard $\sim 48$ million words, whereas those from less affluent families had heard $~ 13$ million. This work as well as other investigations of effects of SES disparity (52-54) have been widely publicized and are being utilized by the American Academy of Pediatrics (55), The Too Small to Fail Campaign, a joint initiative of the Bill, Hillary, \& Chelsea Clinton Foundation and Next Generation (56), and the Thirty Million Words Initiative (57) to encourage early literacy.

\section{Language Outcome at Age 2 y}

Researchers have shown differences in language development at even younger ages than those reported by Hart and Risley. Fernald et al. (45) investigated SES differences in language processing skill and vocabulary in 48 infants who were followed longitudinally from 18 to 24 mo. SES levels were determined using the Hollingshead Four Factor Index $(58,59)$ and maternal education. All children were from monolingual Englishspeaking families. The high-SES group was significantly more advanced in its vocabulary than those in the lower SES group at $18 \mathrm{mo}$, with the divergence widening at $24 \mathrm{mo}$. At $24 \mathrm{mo}$, the higher SES children produced nearly 450 words on average compared with $\sim 150$ fewer words in the lower SES children (Figure 2). Language processing efficiency also differed, with performance of lower SES children at 24 mo of age being similar to the performance of higher SES at 18 mo of age. Authors suggest next steps to be exploration of the variability

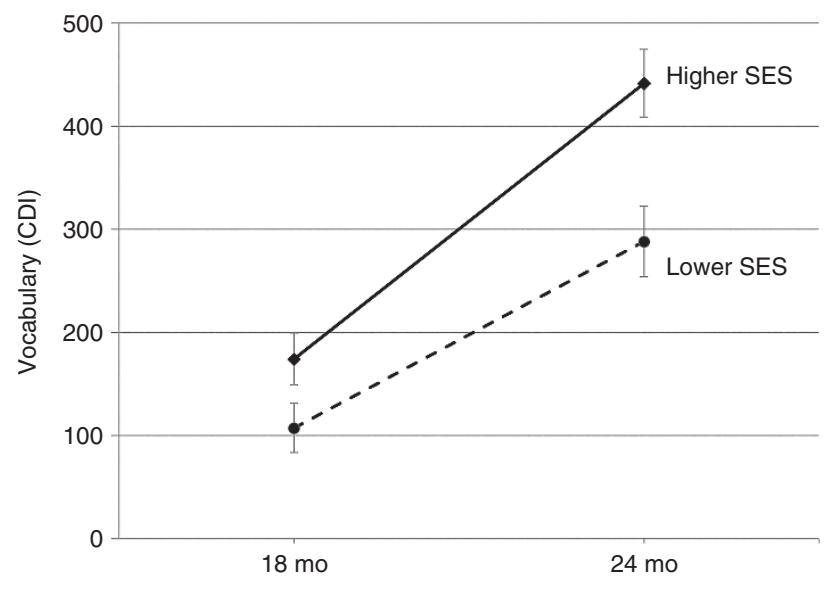

Figure 2. Comparison of vocabulary scores for lower and higher SES children at ages 18 and 24 months on the CDI. Scores represent mean number of spoken words as reported by caregivers. Mean scores for each group are shown with error bars representing SE of the mean. Mixed ANOVA showed age and SES group effects $(P<0.001)$ as well as an age by group interaction $(P=0.02)$. Reprinted with permission from ref. 45. CDI, MacArthur/ Bates Communicative Development Inventory; SES, socioeconomic status.

in early experiences that contribute to differences in emerging language development and to conduct these investigations in larger and more diverse samples.

Another recent study investigated SES disparity on language performance through assessments utilizing The Bayley Scales of Infant Development II in a cohort of prior preterm $(\leq 32 \mathrm{wk})$ infants half of whom were low SES and half of whom were of higher SES (46). In this study, receipt of Medicaid-type insurance was utilized as a proxy for lower SES (60-62). The infants, 65 in families with Medicaid-type insurance and 65 in families with private insurance (matched for natal course), were evaluated at a mean of 22 mo corrected age by psychologists masked to insurance status. Infants with Medicaid-type insurance scored nearly 1 full SD lower than those with private insurance ( 87.9 vs. $101.9, P<0.001)$. Results were similar in the cognitive domain (94.0 vs. 106.0, $P<0.001)$. Thus, taken together, the investigations described here demonstrate an early and profound effect of SES on language performance in young children.

\section{Language: Quality vs. Quantity}

The importance of the quality of shared language between adults and children is receiving increasing attention. Rowe describes use of a diverse and sophisticated vocabulary, in addition to SES and input quantity, as influential in early vocabulary development (63). Similarly, Weisleder and Fernald report that a richer language experience, such as child-directed speech, strengthens skills necessary for facilitation of language growth (64). While quantity of words heard was emphasized in Hart and Risley's work they, too, found the amount of parenting per hour and the quality of verbal content utilized in parenting were strongly related to both parental SES and to the IQ of the child (50). Recently, Hirsch-Pasek, in a study of 2-y olds from low-income families, showed that quality interactions with words (use of shared symbols and conversational fluency) 
was a better predictor of language outcome at age $3 \mathrm{y}$ than the quantity of words to which the child had been exposed (65). Overall, in addition to quantity, there is a growing consensus that the quality of parent-child verbal interaction is of crucial importance to language development.

\section{How Does Poverty Affect Language and Cognitive Development?}

Numerous environmental factors have the potential to affect language outcome-instability of social and parental support structure, parenting style, maternal speech, nutrition, toxin exposure, exposure to violence, and other prenatal and postnatal stressors $(49,66,67)$. Perkins et al. $(47)$ reduce these factors to two intertwined pathways-family stress and parenting. They describe parenting style, language use, and home literacy environment as powerful influences on language development, emphasizing the influence challenging environments may have on parental emotional distress. Genetics must be considered as well. In this regard, research in twins has shown that environmental factors are more influential than genetics in cognitive outcome of youth reared in low-SES environments $(68,69)$. For example, in a sample from families of diverse SES, Turkheimer et al. (69) found that shared environment accounted for $60 \%$ of variance in cognitive abilities in low-SES subjects with genetic contribution being virtually zero, with the reverse being true for subjects of higher SES. These findings underscore the importance of providing enriched environments for children from socioeconomically challenging circumstances.

\section{POVERTY AND THE BRAIN}

Neuroimaging of infants and children is providing remarkable knowledge regarding normative brain development, with many studies relating findings to neurocognitive function (70-72). While fewer in number, investigations of the early neural structural correlates of poverty are emerging. As early differences in brain structure have been linked to cognitive development (73-77), elucidation of the neural effects of SES can inform regarding underlying mechanisms for altered neurocognitive performance, provide opportunities for targeted interventions, and perhaps drive policy change to reduce SES disparities $(78,79)$.

Neuroimaging in Older Children From Diverse SES Environments The studies described below have in common the quest to better understand the relation between SES and brain structure. That said, one study may differ from another in cohort size, age at which images were obtained, SES indicators, regions of interest, environmental variables assessed, and other factors. For the studies cited, we provide descriptors in general with additional details in Table 1.

Utilizing income-to-needs ratio (constructed from family income and family size) as a marker for poverty, Luby et al. (24) found that early exposure to poverty was associated with smaller cortical gray and white matter as well as smaller left hippocampal and left amygdala volumes in children imaged at ages 6-12 y. These SES effects were examined for mediation by three factors commonly associated with SES: caregiver education, supportive/hostile parenting, and children's experience of stressful life events. The relation between SES and white matter and gray matter volumes was not mediated by any of the three factors. However, SES effects on hippocampal volume were fully mediated by caregiving behavior, a finding consistent with reports of hippocampal sensitivity to parental behaviors in both animal and human studies $(80,81)$. A limitation of this study was use of a sample of preschoolers oversampled for symptoms of depression, thus limiting generalizability.

Noble et al. (82) conducted an investigation in 60 socioeconomically diverse children (as determined by income-toneeds and parental education) evaluated at a mean age of 11.4 y. Stepwise regressions with SES variables entered separately in the model showed that, after controlling for age, total cortical volume, and sex, higher income-to-needs was associated with larger hippocampal volume and lower parental education was associated with larger amygdala volumes. Authors caution that firm conclusions were difficult to establish in this cross-sectional sample of 60 children. No environmental factors were evaluated as potential mediators (82).

In a study exploring effects of SES on cortical thickness in 283 healthy children and adolescents between ages 4 and $18 \mathrm{y}$ of age, Lawson et al. (83) found that lower parental education predicted decreased cortical thickness in anterior cingulate and superior frontal gyrus (prefrontal cortex), suggesting a link between SES and cognitive function. In this investigation, SES was defined by income-to-needs and parental education, however, only parental education was associated with outcomes. As with Noble et al., these authors suggest investigations of SES and specific environmental factors are necessary to identify mediators through which SES affects child development.

A more recent investigation by Noble et al. (84) reports effects of SES in a large cross-sectional study of 1,099 children and youth (magnetic resonance imaging (MRI) at mean age of 11.9 y). SES was defined as family income and parental education, with results showing that increasing income (not education) was logarithmically associated with increasing surface area of the brain. This relationship was stronger at the lower end of the SES spectrum than at the higher end of the spectrum. As is true for other reports, conclusions were limited by the cross-sectional nature of the investigation as well as inability to define particular links driving the association between SES and brain structure. Despite differences and limitations (see Table 1), these studies taken together provide consensus that SES influences neuroanatomy in children and youth. However, less is known regarding this relationship in younger infants and toddlers.

\section{Neuroimaging in Young Children From Diverse SES Environments}

Given the above findings in cohorts of older children, there is growing interest in SES effects on neuroanatomy at younger ages. Investigating this relationship in younger children is particularly compelling as neural development during the first year is dynamic, characterized by complex patterns of growth in gray matter (85), myelination, and synaptic pruning $(86,87)$. 
Table 1. SES effects on MRI outcomes: study characteristics ${ }^{\mathrm{a}}$

\begin{tabular}{|c|c|c|c|c|c|c|c|}
\hline & $\begin{array}{c}\text { Age of subjects } \\
\text { Sample size (\#female) } \\
\text { Race/ethnicity }\end{array}$ & Study design & SES variable & $\begin{array}{l}\text { Neuroimaging: } \\
\text { outcome } \\
\text { measures }\end{array}$ & Results & Strengths & Limitations \\
\hline $\begin{array}{l}\text { Betancourt } \\
\text { et al. (91) }\end{array}$ & $\begin{array}{l}\text { - } 4-6 \text { wk (mean } 5 \text { wk) } \\
\text { - } n=44 \text { (44 F) } \\
\text { - } 100 \% \text { African } \\
\text { American }\end{array}$ & $\begin{array}{l}\text { - Cross- } \\
\text { sectional } \\
\text { (repeated } \\
\text { MRls in } \\
\text { progress) } \\
\text { - Masked raters }\end{array}$ & $\begin{array}{l}\text { Composite: } \\
\text { - ITN } \\
\text { - Maternal } \\
\text { education } \\
\end{array}$ & $\begin{array}{l}\text { Volume: } \\
\text { - White matter } \\
\text { - Gray matter } \\
\text { - Deep gray } \\
\text { matter }\end{array}$ & $\begin{array}{l}\text { Lower SES associated } \\
\text { with smaller volumes } \\
\text { of cortical and deep } \\
\text { gray matter. }\end{array}$ & $\begin{array}{l}\text { - Sample controlled } \\
\text { for gender and } \\
\text { race/ethnicity } \\
\text { - Early age at scan }\end{array}$ & $\begin{array}{l}\text { - Sample size } \\
\text { - Single sex, race/ } \\
\text { ethnicity } \\
\text { - Mediators not } \\
\text { examined }\end{array}$ \\
\hline $\begin{array}{l}\text { Luby } \\
\text { et al. (24) }\end{array}$ & $\begin{array}{l}\text { - } 6-12 \text { y (mean 9.8) } \\
\text { - } n=145 \text { (73 F) } \\
\text { - } \text { Diverse } \\
\text { race/ethnicity }\end{array}$ & $\begin{array}{l}\text { - Cross- } \\
\text { sectional } \\
\text { - Masked raters }\end{array}$ & - ITN & $\begin{array}{l}\text { Volume: } \\
\text { - White matter } \\
\text { - Gray matter } \\
\text { - Hippocampus } \\
\text { - Amygdala }\end{array}$ & $\begin{array}{l}\text { Lower ITN associated } \\
\text { with smaller white and } \\
\text { cortical gray matter, } \\
\text { hippocampus, and } \\
\text { amygdala volumes. } \\
\text { Effects on } \\
\text { hippocampus } \\
\text { mediated by caregiver } \\
\text { behavior and life stress. }\end{array}$ & $\begin{array}{l}\text { - Sample size } \\
\text { - Examined ROIs } \\
\text { - Mediators } \\
\text { examined } \\
\end{array}$ & $\begin{array}{l}\text { - Oversampled } \\
\text { preschoolers with } \\
\text { depression }\end{array}$ \\
\hline $\begin{array}{l}\text { Noble } \\
\text { et al. (84) }\end{array}$ & $\begin{array}{l}\text { - 3-20 y (mean 11.9) } \\
\text { - } n=1099 \text { (531 F) } \\
\text { - Diverse race/ } \\
\text { ethnicity }\end{array}$ & $\begin{array}{l}\text { - Cross- } \\
\text { sectional }\end{array}$ & $\begin{array}{l}\text { - Family } \\
\text { income } \\
\text { - Parental } \\
\text { education }\end{array}$ & $\begin{array}{l}\text { Volume } \\
\text { Thickness } \\
\text { Surface area: } \\
\text { - } 21 \text { ROls }\end{array}$ & $\begin{array}{l}\text { Lower income } \\
\text { associated with } \\
\text { smaller surface area } \\
\text { (effects stronger in } \\
\text { low income range). }\end{array}$ & $\begin{array}{l}\text { - Sample size } \\
\text { - Examined ROls } \\
\text { - Examined general } \\
\text { ancestry factor }\end{array}$ & $\begin{array}{l}\text { - Broad age range } \\
\text { - Mediators not } \\
\text { examined } \\
\text { - Income indicator } \\
\text { does not account } \\
\text { for family size } \\
\text { - Multiple } \\
\text { comparisons }\end{array}$ \\
\hline $\begin{array}{l}\text { Raizada } \\
\text { et al. (89) }\end{array}$ & $\begin{array}{l}\text { - } 5-5.7 \text { y (mean } 5.3 \text { y) } \\
\text { - } n=14 \text { (7F) } \\
\text { - } \text { Race/ethnicity not } \\
\text { specified }\end{array}$ & $\begin{array}{l}\text { - Cross- } \\
\text { sectional }\end{array}$ & $\begin{array}{l}\text { Composite: } \\
\text { - Parental } \\
\text { education } \\
\text { - Occupation }\end{array}$ & $\begin{array}{l}\text { Volume: inferior } \\
\text { frontal gyrus } \\
\text { - White matter } \\
\text { - Gray matter }\end{array}$ & $\begin{array}{l}\text { Lower SES associated } \\
\text { with smaller volumes } \\
\text { of gray and white } \\
\text { matter of inferior } \\
\text { frontal gyrus. }\end{array}$ & $\begin{array}{l}\text { Focus on area } \\
\text { associated with } \\
\text { specific cognitive } \\
\text { domain }\end{array}$ & $\begin{array}{l}\text { - Sample size } \\
\text { - Mediators not } \\
\text { examined }\end{array}$ \\
\hline
\end{tabular}

Arranged alphabetically by first author.

ITN, income-to-needs; MRI, magnetic resonance imaging; ROIs, regions of interest; SES, socioeconomic status. Masked Raters, raters masked to subject characteristics.

Moreover, there is increasing recognition that growth and development of neural structures during infancy provide the foundation for both concurrent and later cognitive processes $(73,74,76,77,88)$.
Among the youngest children analyzed for SES effects on brain structure are those reported by Raizada et al. (89). In 14 children of diverse SES $(58,59)$ who underwent functional MRI at age $5 \mathrm{y}$, SES predicted hemispheric specialization of the 
left inferior frontal gyrus during a rhyming task predictive of reading skills. The inferior frontal gyrus contains Broca's area, associated with speech and language function. Correlations also were found between SES and gray and white matter volumes of the inferior frontal gyrus, with lower SES children demonstrating smaller volumes. These findings, although in a small cohort, are of particular interest given the linkages of SES and language performance in older children.

In another investigation, growth trajectories of deep gray matter were examined in a cohort of 77 children, with mean age at first MRI of 13.5 mo (90). A total of 203 scans were obtained. Visual inspection of growth curves for total gray matter for this sample of low-, middle-, and high-income children shows overlap at 5 mo of age with divergence of the three groups only later. Analyses showed significantly slower rate of growth for the low-income group compared to the highincome group (Figure 3). A unique strength of this study was completion of repeated scans in some subjects over time allowing for construction of trajectories.

More recently, in an ongoing study, differences in brain volume were reported in 44 healthy term female AfricanAmerican infants from varying SES backgrounds as determined by income-to-needs and parental education. Cortical gray and deep gray matter volumes were smaller in infants of lower SES than their wealthier counterparts at mean age of $5 \mathrm{wk}$, the earliest reported age at which such effects have been detected (91). The single race/ethnicity/sex design of this study coupled with the very early age at MRI ( $5 \mathrm{wk}$ ) are unique strengths of this endeavor. In sum, given results of studies cited, neural effects of SES are being described at increasingly younger ages with the most recent being at the surprisingly early age of $5 \mathrm{wk}$.

While we know of no other studies of SES effects on brain structure at young ages, there are reports of SES-related differences in functional brain activity within the first year of life. Tomalski et al. (92) reported electroencephalogram differences

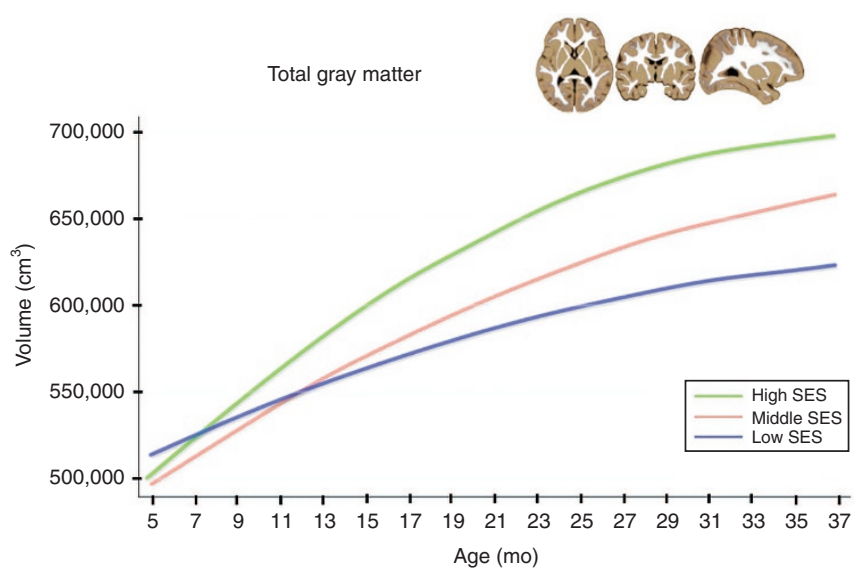

Figure 3. Growth trajectories of total gray matter volume for low-, middle-, and high-SES groups by age. Age in months is shown on the horizontal axis, spanning from 5 to 37 months. Total gray matter volume is shown on the vertical axis. The blue line shows children from low SES households; children from middle SES households are shown in red. The green line shows children from high SES households. Reprinted under Creative Commons 4.0 license, from ref. 90. SES, socioeconomic status. between low- and middle-SES infants at 6 and 9 mo of age with Gao et al. (18) reporting marginal effects of SES on functional MRI resting functional connectivity at 6 mo of age. These studies complement the neuroanatomical findings and underscore the impact of the environment on children at very young ages.

\section{How Does Poverty Affect the Brain?}

As with effects of poverty on language, factors likely associated with neural changes include environmental toxins, nutrition, cognitive stimulation, parental education, various forms of deprivation, and stressors for family and child. Perhaps the most egregious example of deprivation is from studies of Romanian orphans in which early institutionalization changed the structure and the function of the brain $(93,94)$. Decreases in gray and white matter were shown for those who remained in orphanages rather than being placed in foster care where more secure attachments could be established. Although the stressors and "toxic environments" in which some children are raised are far less harsh than those experienced by the Romanian orphans, they potentially are injurious to the developing brain (19). Future investigations are necessary to fully parse the specific environmental factors and duration of exposure associated with neural effects.

\section{DISCUSSION}

There are $~ 16$ million children growing up poor in America today with the majority, 11 million, aged 3 and younger (95). The future for these children remains challenging. Over $40 \%$ of children born in the lowest quintile of family income will remain in the same quintile as adults (96). Why? As described in this review, low SES and early life adversity produce deleterious effects on developmental outcome and brain anatomy.

\section{Implications for Policy and Practice}

Interventions for very young children: models. The plasticity of the brain has been well described (97-100) as have been the beneficial effects of early intervention $(101,102)$. Specifically, the Nurse-Family Partnership in practice for the past three decades, the Abecedarian Project initiated in the 1970s, and the Perry Preschool Project begun in the 1960s with followup to the present demonstrate beneficial effects on child, and even adult outcome (103-106). The Perry Preschool Project which utilized 1-2 y of center-based preschool for 3- and 4-y olds and weekly home visiting that included parent coaching has demonstrated not only short-term cognitive benefits but also long-term benefits on high school graduation rate, home ownership, and reduced incarceration $(79,106)$. While these efforts are exemplary, not all of the myriad intervention services available today utilize the highly skilled personnel or rigorous design of these flagship programs.

Interventions for very young children: current. The current emphasis on universal Pre-K is laudable, however, these interventions may occur well after foundational neural growth. We suggest increased focus on younger ages, with further development of programs and policies such as Early Head Start and 


\section{Review Hurt and Betancourt}

Zero to Three which are directed to reducing the impact of SES disparities in very young children $(56,57,107)$. These endeavors go beyond teaching skills to the child by including caregiver education and training as well. As the neural impact of SES disparity now is being described as early as $5 \mathrm{wk}$ of age, the impetus for realignment of resource allocation is heightened. In this regard, annual appropriations for Early Head Start are being expanded, with $20 \%$ of all Head Start training dollars now allocated to Early Head Start programs (108). This is encouraging, however, only a small portion of low-income children currently are served by federal Early Head Start programs, with the majority of at-risk infants and toddlers without access (108).

Interventions for very young children: fiscal underpinnings. Compelling fiscal analyses underscore the reasonableness of initiating quality interventions in the earliest months. Knudsen et al. (78) have shown that the rates of return on human capital investment at different ages are markedly better the earlier the investment, with the greatest returns being for investment at ages $0-3$ y (Figure 4). Utilizing data primarily from the Perry Preschool Project, Knudsen et al. estimate that a $7-10 \%$ per year return on investment through increased school and career achievement as well as a reduction in costs associated with remedial education, health, and criminal justice system expenditures. For example, in Pennsylvania alone, it is estimated that a $5 \%$ increase in male graduation rates would save the State $\sim$ \$182 million in annual incarceration costs and crime-related expenditures. Furthermore, if that same 5\% went on to college at the same rate as typical male high school graduates, their average earnings would accrue an additional $\sim 106$ million annually $(109,110)$.

Policies for reduction of SES disparities. To detail national and international discourse regarding efforts to reduce SES

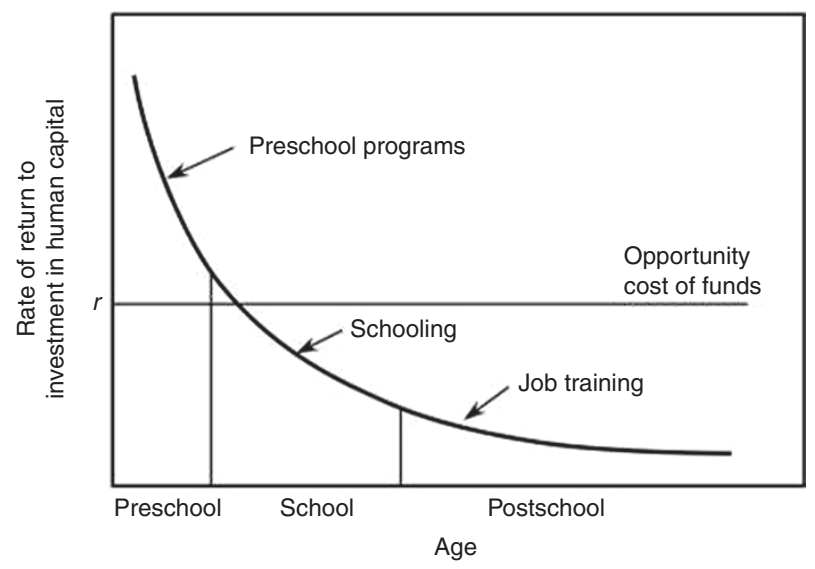

Figure 4. Rates of return to investment in human capital as function of age when the investment was initiated. The data were derived from a life cycle model of dynamic human capital accumulation with multiple periods and credit constraints. Investments were initially set to be equal across all ages. On the y-axis, the symbol " $r$ " represents the Rate of Return to Investment of Human Capital. Reprinted from ref. 78. Copyright (2006) National Academy of Sciences, USA. disparities is beyond the scope of this review. This notwithstanding, effects of challenging environments continue to affect children's futures on a daily basis.

\section{Ongoing and Future Research}

The literature reviewed here provides convincing evidence of the very early effects of challenging environments on the brain and behavior of infants and toddlers. That aside, there remain numerous unresolved issues requiring further investigation. Among these are the following:

What aspects of the prenatal environment affect neural outcome? With reports of SES effects on neural development as early as $5 \mathrm{wk}$ of age, coupled with the established effects of SES on pregnancy outcome $(111,112)$, consideration of the role of prenatal environment on neural development is required. Such prenatal influences include maternal nutrition, exposure to toxins, life stressors, and maternal mental and physical health. In a systematic review by Blumenshine et al. (111), the influence of the individual-level measures of income, education, occupation, and area-based socioeconomic measures were assessed. Authors suggest that socioeconomic factors experienced across a woman's lifetime may be more influential on birth outcome than any one particular factor. Stress, too, has been implicated in adverse birth outcome with maternal psychosocial stress accounting for $7 \%$ of the variance in gestational-adjusted birth weight in African-American pregnancies in one report (112). Studies of effects of SES disparities that utilize prenatal enrollment strategies are needed.

What role do genetics and epigenetics play in early infant neural and developmental outcome? The relation of genetics and epigenetics with SES and neural development is a relatively unexplored yet important field for future endeavors (10). Strong genetic effects on neonatal MRI outcomes have been shown in twin studies (113). Noble et al. (84). examined associations between socioeconomic factors (parent education, family income) and surface area, adjusting for age, scanner site, sex, and genetic ancestry factor The genetic ancestry factor (whole genome single nucleotide polymorphism genotype) indexes general genetic variation associated with ethnicity. In this study, associations between SES factors and brain morphometry did not vary across ancestry groups. The finding of SES effects independent of ancestry is noteworthy as these two variables are commonly confounded in studies of SES effects on outcome. Future endeavors utilizing next-generation sequencing will be useful for identification of genetic variants associated with neural trajectories in infancy and childhood.

What specific regions of the infant brain are affected by SES in young children? Most studies of very young children do not examine specific neural regions associated with emerging cognitive skills. In older children, regions of the brain that are associated with memory, executive function, and regions sensitive to stress show variation according to SES disparity. For example, there are several studies in older children that 
link SES to volume and thickness of the hippocampus and amygdala, areas known to be responsive to stress and to be associated with emotional processes (82). Exploration of such regions of interest in young children is needed to more fully understand: (i) the timing of effects of SES disparity and (ii) the mechanisms leading to SES associated differences in cognitive function observed in older children.

What factors mediate the relation between SES and neural outcome? A common thread in studies reviewed is the lack of clarity regarding which specific aspects of the environment mediate effects of SES on neural outcome. Is parental education more critical than income? What roles do maternal IQ, parenting style, and home environment play? Studies such as those being conducted by Betancourt et al. (91), in which the home environment as well as maternal intelligence and psychosocial status are being evaluated, will begin to provide answers regarding potential causal linkages between SES and neural development.

What is the effect of SES on neural and developmental trajectories? Even though one group of investigators has found smaller cortical and deep gray volumes at $5 \mathrm{wk}$ of age in lower SES infants, whether this difference persists, increases, or abates over time is not known. Moreover, are such volumetric differences associated with altered developmental trajectories? In one ongoing study, MRIs and developmental evaluations are being repeated at 12 and 24 mo so that SES effects on trajectories of neural growth, developmental outcome, and their relation can be examined (91). Providing answers to the queries posed here is critical to improved understanding of the mutability or immutability of SES effects and only will come from carefully conducted longitudinal investigations.

What are the opportunities and challenges in infant imaging research? Opportunities for the study of infant neural development are increasing due to the remarkable imaging and processing technologies that have emerged over the past decade. These technologies allow for study not only of volume, thickness, and surface area of the rapidly developing infant brain but also have led to projects designed to map the neural connections across the brain both at rest and during specific cognitive activities $(114,115)$. Despite these exciting new opportunities, one of the most daunting challenges in infant imaging is motion artifact because MRI examination of healthy infants does not allow for sedation. Scans in unsedated infants are associated with lower success rates and, paired with the high cost of scanner time, create a significant hurdle for researchers (116). In terms of reliability of measurements, infant templates for parcellation of neuroimages are not well established. Development of such templates will provide tools for reliable and accurate region of interestbased infant studies (117). Taken together, the rapid and ongoing progress in the field of imaging technology provides exciting opportunities for advancing infant brain development research.

\section{COMMENT}

In closing, the concerning findings reported here are in no way meant to suggest that early effects of SES disparities are immutable. Rather, these findings support continued exploration of the influence of both prenatal and postnatal factors on neural development. Whatever the cause of SES-related differences, the existence of such differences so early in life suggests that interventions cannot begin too early in support of young children and their families.

\section{ACKNOWLEDGMENTS}

The authors thank Nancy Brodsky, PhD, Kristin Arena, and Maureen Fleming for their invaluable assistance in preparation of this manuscript.

\section{STATEMENT OF FINANCIAL SUPPORT}

No financial support was received for preparation of this review.

Disclosures: There are no prior publications or submissions with any overlapping information, including studies and patients. Each author listed on the manuscript has seen and approved the submission and takes full responsibility for the manuscript. We have no conflicts of interest to resolve.

\section{REFERENCES}

1. Goodman E. The role of socioeconomic status gradients in explaining differences in US adolescents' health. Am J Public Health 1999;89:1522-8.

2. Sirin SR. Socioeconomic status and academic achievement: a meta-analytic review of research. Rev Ed Res 2005;75:417-53.

3. Kessler RC, Berglund P, Demler O, Jin R, Merikangas KR, Walters EE. Lifetime prevalence and age-of-onset distributions of DSM-IV disorders in the National Comorbidity Survey Replication. Arch Gen Psychiatry 2005;62:593-602.

4. Noble KG, Norman MF, Farah MJ. Neurocognitive correlates of socioeconomic status in kindergarten children. Dev Sci 2005;8:74-87.

5. Farah MJ, Shera DM, Savage JH, et al. Childhood poverty: specific associations with neurocognitive development. Brain Res 2006;1110:166-74.

6. Noble KG, McCandliss BD, Farah MJ. Socioeconomic gradients predict individual differences in neurocognitive abilities. Dev Sci 2007;10:464-80.

7. Kishiyama MM, Boyce WT, Jimenez AM, Perry LM, Knight RT. Socioeconomic disparities affect prefrontal function in children. J Cogn Neurosci 2009;21:1106-15.

8. Pungello EP, Iruka IU, Dotterer AM, Mills-Koonce R, Reznick JS. The effects of socioeconomic status, race, and parenting on language development in early childhood. Dev Psychol 2009;45:544-57.

9. Sheridan MA, Sarsour K, Jutte D, D’Esposito M, Boyce WT. The impact of social disparity on prefrontal function in childhood. PLoS One 2012;7:e35744.

10. Boyce WT, Sokolowski MB, Robinson GE. Toward a new biology of social adversity. Proc Natl Acad Sci USA 2012;109:Suppl 2:17143-8.

11. Nisbett RE, Aronson J, Blair C, et al. Intelligence: new findings and theoretical developments. Am Psychol 2012;67:130-59.

12. Malter Cohen M, Jing D, Yang RR, Tottenham N, Lee FS, Casey BJ. Earlylife stress has persistent effects on amygdala function and development in mice and humans. Proc Natl Acad Sci USA 2013;110:18274-8.

13. Buss C, Lord C, Wadiwalla M, et al. Maternal care modulates the relationship between prenatal risk and hippocampal volume in women but not in men. J Neurosci 2007;27:2592-5.

14. Dipietro JA. Maternal stress in pregnancy: considerations for fetal development. J Adolesc Health 2012;51:Suppl 2:S3-8.

15. Hackman DA, Farah MJ, Meaney MJ. Socioeconomic status and the brain: mechanistic insights from human and animal research. Nat Rev Neurosci 2010;11:651-9.

16. Cordero JF. Effect of environmental agents on pregnancy outcomes: disturbances of prenatal growth and development. Med Clin North Am 1990;74:279-90.

17. Boyce WT, Kobor MS. Development and the epigenome: the 'synapse' of gene-environment interplay. Dev Sci 2015;18:1-23. 
18. Gao W, Alcauter S, Elton A, et al. Functional network development during the first year: relative sequence and socioeconomic correlations. Cereb Cortex 2015;25:2919-28.

19. Shonkoff JP, Garner AS, Siegel BS, et al. The lifelong effects of early childhood adversity and toxic stress. Pediatrics 2012;129:e232-46.

20. McEwen BS. Stressed or stressed out: what is the difference? J Psychiatry Neurosci 2005;30:315-8.

21. McEwen BS. Protective and damaging effects of stress mediators: central role of the brain. Dialogues Clin Neurosci 2006;8:367-81.

22. Hackman DA, Farah MJ. Socioeconomic status and the developing brain. Trends Cogn Sci 2009;13:65-73.

23. Nelson CA. Biological embedding of early life adversity. JAMA Pediatr 2013;167:1098-100.

24. Luby J, Belden A, Botteron K, et al. The effects of poverty on childhood brain development: the mediating effect of caregiving and stressful life events. JAMA Pediatr 2013;167:1135-42.

25. Durham RE, Farkas G, Hammer CS, Bruce Tomblin J, Catts HW. Kindergarten oral language skill: A key variable in the intergenerational transmission of socioeconomic status. Res Soc Stratification Mobility 2007;25: 294-305.

26. Hurt H, Brodsky NL, Betancourt L, Braitman LE, Malmud E, Giannetta J. Cocaine-exposed children: follow-up through 30 months. J Dev Behav Pediatr 1995;16:29-35.

27. Hurt H, Brodsky NL, Braitman LE, Giannetta J. Natal status of infants of cocaine users and control subjects: a prospective comparison. J Perinatol 1995;15:297-304.

28. Hurt H, Brodsky NL, Betancourt L, Braitman LE, Belsky J, Giannetta J. Play behavior in toddlers with in utero cocaine exposure: a prospective, masked, controlled study. J Dev Behav Pediatr 1996;17:373-9.

29. Hurt H, Malmud E, Betancourt L, Braitman LE, Brodsky NL, Giannetta J. Children with in utero cocaine exposure do not differ from control subjects on intelligence testing. Arch Pediatr Adolesc Med 1997;151:1237-41.

30. Hurt H, Malmud E, Betancourt L, Brodsky NL, Giannetta J. A prospective evaluation of early language development in children with in utero cocaine exposure and in control subjects. J Pediatr 1997;130:310-2.

31. Betancourt L, Fischer R, Giannetta J, Malmud E, Brodsky NL, Hurt H. Problem-solving ability of inner-city children with and without in utero cocaine exposure. J Dev Behav Pediatr 1999;20:418-24.

32. Hurt H, Giannetta J, Brodsky NL, Malmud E, Pelham T. Are there neurologic correlates of in utero cocaine exposure at age 6 years? J Pediatr 2001;138:911-3.

33. Hurt H, Malmud E, Betancourt LM, Brodsky NL, Giannetta JM. A prospective comparison of developmental outcome of children with in utero cocaine exposure and controls using the Battelle Developmental Inventory. J Dev Behav Pediatr 2001;22:27-34.

34. Hurt H, Brodsky NL, Roth H, Malmud E, Giannetta JM. School performance of children with gestational cocaine exposure. Neurotoxicol Teratol 2005;27:203-11.

35. Avants BB, Hurt H, Giannetta JM, et al. Effects of heavy in utero cocaine exposure on adolescent caudate morphology. Pediatr Neurol 2007;37: 275-9.

36. Rao H, Wang J, Giannetta J, et al. Altered resting cerebral blood flow in adolescents with in utero cocaine exposure revealed by perfusion functional MRI. Pediatrics 2007;120:e1245-54.

37. Hurt H, Giannetta JM, Korczykowski M, et al. Functional magnetic resonance imaging and working memory in adolescents with gestational cocaine exposure. J Pediatr 2008;152:371-7.

38. Hurt H, Betancourt LM, Malmud EK, et al. Children with and without gestational cocaine exposure: a neurocognitive systems analysis. Neurotoxicol Teratol 2009;31:334-41.

39. Betancourt LM, Yang W, Brodsky NL, et al. Adolescents with and without gestational cocaine exposure: longitudinal analysis of inhibitory control, memory and receptive language. Neurotoxicol Teratol 2011;33: 36-46.

40. Wechsler D. The Wechsler Preschool and Primary Scale of IntelligenceRevised. San Antonio, TX: The Psychological Corp., 1989.
41. Hurt H, Malmud E, Braitman LE, Betancourt LM, Brodsky NL, Giannetta JM. Inner-city achievers: who are they? Arch Pediatr Adolesc Med 1998;152:993-7.

42. Krauss RB, Thurman SK, Brodsky N, Betancourt L, Giannetta J, Hurt H. Caregiver interaction behavior with prenatally cocaine-exposed and nonexposed preschoolers. J Early Intervention 2000;23:62-73.

43. Gross SJ, Slagle TA, D'Eugenio DB, Mettelman BB. Impact of a matched term control group on interpretation of developmental performance in preterm infants. Pediatrics 1992;90:681-7.

44. Sheridan SM, Knoche LL, Kupzyk KA, Edwards CP, Marvin CA. A randomized trial examining the effects of parent engagement on early language and literacy: the Getting Ready intervention. J Sch Psychol 2011;49:361-83.

45. Fernald A, Marchman VA, Weisleder A. SES differences in language processing skill and vocabulary are evident at 18 months. Dev Sci 2013;16: 234-48.

46. Wild KT, Betancourt LM, Brodsky NL, Hurt H. The effect of socioeconomic status on the language outcome of preterm infants at toddler age. Early Hum Dev 2013;89:743-6.

47. Perkins SC, Finegood ED, Swain JE. Poverty and language development: roles of parenting and stress. Innov Clin Neurosci 2013;10:10-9.

48. Burchinal MR, Roberts JE, Zeisel SA, Rowley SJ. Social risk and protective factors for African American children's academic achievement and adjustment during the transition to middle school. Dev Psychol 2008;44:286-92.

49. Hoff E. The specificity of environmental influence: socioeconomic status affects early vocabulary development via maternal speech. Child Dev 2003;74:1368-78.

50. Hart B, Risley TR. American parenting of language-learning children: persisting differences in family child interactions observed in natural home environments. Dev Psychol 1992;28:1096-105.

51. Hart B, Risley TR. Meaningful Differences in the Everyday Experience of Young American Children. Baltimore, MD: Brookes Publishing Company, 1995.

52. Vasilyeva M, Waterfall H, Huttenlocher J. Emergence of syntax: commonalities and differences across children. Dev Sci 2008;11:84-97.

53. NICHD Early Child Care Research Network. The relation of child care to cognitive and language development. Child Dev 2000;71:960-80.

54. Stein A, Malmberg LE, Sylva K, Barnes J, Leach P. The influence of maternal depression, caregiving, and socioeconomic status in the post-natal year on children's language development. Child Care Health Dev 2008;34: 603-12.

55. High PC, Klass P. Literacy promotion: an essential component of primary care pediatric practice. Pediatr 2014;134:404-9.

56. Next Generation and the Bill Hillary \& Chelsea Clinton Foundation. Preparing America's Children for Success in the 21st Century: Too Small to Fail, 2013. (https://www.clintonfoundation.org/sites/default/files/2s2f_ framingreport_v2r3.pdf.)

57. Suskind D. Thirty Million Words Initiative, 2014. (http://tmw.org/.)

58. Hollingshead AB. Four-Factor Index of Social Status. New Haven, CT: Department of Sociology, Yale University, 1975.

59. Hollingshead AB, Redlich FC. Social class and mental illness: a community study. 1958. Am J Public Health 2007;97:1756-7.

60. Marcin JP, Schembri MS, He J, Romano PS. A population-based analysis of socioeconomic status and insurance status and their relationship with pediatric trauma hospitalization and mortality rates. Am J Public Health 2003;93:461-6

61. Buck GM, Msall ME, Schisterman EF, Lyon NR, Rogers BT. Extreme prematurity and school outcomes. Paediatr Perinat Epidemiol 2000;14: 324-31.

62. Schechter MS, Margolis PA. Relationship between socioeconomic status and disease severity in cystic fibrosis. J Pediatr 1998;132:260-4.

63. Rowe ML. A longitudinal investigation of the role of quantity and quality of child-directed speech in vocabulary development. Child Dev 2012;83:1762-74.

64. Weisleder A, Fernald A. Talking to children matters: early language experience strengthens processing and builds vocabulary. Psychol Sci 2013;24:2143-52. 
65. Quenqua D. Quality of words, not quantity, is crucial to language skills, study finds. New York Times, October 16, 2014. (http://www.nytimes. com/2014/10/17/us/quality-of-words-not-quantity-is-crucial-to-language-skills-study-finds.html?_r=0.)

66. Laplante DP, Barr RG, Brunet A, et al. Stress during pregnancy affects general intellectual and language functioning in human toddlers. Pediatr Res 2004;56:400-10.

67. Whitehouse AJ, Robinson M, Zubrick SR, Ang QW, Stanley FJ, Pennell CE. Maternal life events during pregnancy and offspring language ability in middle childhood: The Western Australian Pregnancy Cohort Study. Early Hum Dev 2010;86:487-92.

68. Oliver B, Dale PS, Plomin R. Verbal and nonverbal predictors of early language problems: an analysis of twins in early childhood back to infancy. J Child Lang 2004;31:609-31.

69. Turkheimer E, D'Onofrio BM, Maes HH, Eaves LJ. Analysis and interpretation of twin studies including measures of the shared environment. Child Dev 2005;76:1217-33.

70. Brain Development Cooperative Group. Total and regional brain volumes in a population-based normative sample from 4 to 18 years: the NIH MRI Study of Normal Brain Development. Cereb Cortex 2012;22:1-12.

71. Shaw P, Kabani NJ, Lerch JP, et al. Neurodevelopmental trajectories of the human cerebral cortex. J Neurosci 2008;28:3586-94.

72. Giedd JN, Blumenthal J, Jeffries NO, et al. Brain development during childhood and adolescence: a longitudinal MRI study. Nat Neurosci 1999;2:861-3.

73. Deniz Can D, Richards T, Kuhl PK. Early gray-matter and white-matter concentration in infancy predict later language skills: a whole brain voxelbased morphometry study. Brain Lang 2013;124:34-44.

74. Deoni SC, O'Muircheartaigh J, Elison JT, et al. White matter maturation profiles through early childhood predict general cognitive ability. Brain Struct Funct, e-pub ahead of print 29 November, 2014, (doi:10.1007/s00429-014-0947-x).

75. Ortiz-Mantilla S, Choe MS, Flax J, Grant PE, Benasich AA. Associations between the size of the amygdala in infancy and language abilities during the preschool years in normally developing children. Neuroimage 2010;49:2791-9.

76. Short SJ, Elison JT, Goldman BD, et al. Associations between white matter microstructure and infants' working memory. Neuroimage 2013;64:156-66.

77. Spann MN, Bansal R, Rosen TS, Peterson BS. Morphological features of the neonatal brain support development of subsequent cognitive, language, and motor abilities. Hum Brain Mapp 2014;35:4459-74.

78. Knudsen EI, Heckman JJ, Cameron JL, Shonkoff JP. Economic, neurobiological, and behavioral perspectives on building America's future workforce. Proc Natl Acad Sci USA 2006;103:10155-62.

79. Shonkoff JP. Changing the narrative for early childhood investment. JAMA Pediatr 2014;168:105-6.

80. Liu D, Diorio J, Day JC, Francis DD, Meaney MJ. Maternal care, hippocampal synaptogenesis and cognitive development in rats. Nat Neurosci 2000;3:799-806.

81. Farah MJ, Betancourt L, Shera DM, et al. Environmental stimulation, parental nurturance and cognitive development in humans. Dev Sci 2008;11:793-801.

82. Noble KG, Houston SM, Kan E, Sowell ER. Neural correlates of socioeconomic status in the developing human brain. Dev Sci 2012;15:516-27.

83. Lawson GM, Duda JT, Avants BB, Wu J, Farah MJ. Associations between children's socioeconomic status and prefrontal cortical thickness. Dev Sci 2013;16:641-52.

84. Noble KG, Houston SM, Brito NH, et al. Family income, parental education and brain structure in children and adolescents. Nat Neurosci 2015;18:773-8.

85. Knickmeyer RC, Gouttard S, Kang C, et al. A structural MRI study of human brain development from birth to 2 years. J Neurosci 2008;28:2176-82.

86. Dubois J, Dehaene-Lambertz G, Kulikova S, Poupon C, Hüppi PS, Hertz-Pannier L. The early development of brain white matter: a review of imaging studies in fetuses, newborns and infants. Neuroscience 2014;276:48-71.

87. Uda S, Matsui M, Tanaka C, et al. Normal development of human brain white matter from infancy to early adulthood: a diffusion tensor imaging study. Dev Neurosci 2015;37:182-94.
88. Jednoróg K, Altarelli I, Monzalvo K, et al. The influence of socioeconomic status on children's brain structure. PLoS One 2012;7:e42486.

89. Raizada RD, Richards TL, Meltzoff A, Kuhl PK. Socioeconomic status predicts hemispheric specialisation of the left inferior frontal gyrus in young children. Neuroimage 2008;40:1392-401.

90. Hanson JL, Hair N, Shen DG, et al. Family poverty affects the rate of human infant brain growth. PLoS One 2013;8:e80954.

91. Betancourt LM, Brodsky NL, Wu J, et al. Effect of socioeconomic status (SES) disparity on neural development in female African-American infants at age 1 month. Dev Sci, e-pub ahead of print 21 October 2015, (doi:10.1111/desc.12344).

92. Tomalski P, Moore DG, Ribeiro H, et al. Socioeconomic status and functional brain development - associations in early infancy. Dev Sci 2013;16:676-87.

93. Almas AN, Degnan KA, Radulescu A, Nelson CA 3rd, Zeanah CH, Fox NA. Effects of early intervention and the moderating effects of brain activity on institutionalized children's social skills at age 8. Proc Natl Acad Sci USA 2012;109:Suppl 2:17228-31.

94. Nelson CA 3rd, Fox NA, Zeanah CH Jr. Anguish of the abandoned child. Sci Am 2013;308:62-7.

95. Canada G. A new war with a clear emphasis. New York Times, 5 January 2014. (http://www.nytimes.com/roomfordebate/2014/01/05/does-theus-need-another-war-on-poverty/a-new-war-on-poverty-with-aclear-emphasis.)

96. Bailey MJ. Why we need another war on poverty. New York Times, 5 January2014.(http://www.nytimes.com/roomfordebate/2014/01/05/doesthe-us-need-another-war-on-poverty/why-we-need-another-war-onpoverty.)

97. Stiles J. Neural plasticity and cognitive development. Dev Neuropsychol 2000;18:237-72.

98. van Praag H, Kempermann G, Gage FH. Neural consequences of environmental enrichment. Nat Rev Neurosci 2000;1:191-8.

99. McEwen BS, Gianaros PJ. Stress- and allostasis-induced brain plasticity. Annu Rev Med 2011;62:431-45.

100. Webb AR, Heller HT, Benson CB, Lahav A. Mother's voice and heartbeat sounds elicit auditory plasticity in the human brain before full gestation. Proc Natl Acad Sci USA 2015;112:3152-7.

101. Reynolds AJ, Temple JA, Robertson DL, Mann EA. Long-term effects of an early childhood intervention on educational achievement and juvenile arrest: a 15-year follow-up of low-income children in public schools. JAMA 2001;285:2339-46.

102. Rose L, Herzig LD, Hussey-Gardner B. Early intervention and the role of pediatricians. Pediatr Rev 2014;35:e1-10.

103. Campbell FA, Pungello EP, Burchinal M, et al. Adult outcomes as a function of an early childhood educational program: an Abecedarian Project follow-up. Dev Psychol 2012;48:1033-43.

104. Ramey CT, Campbell FA. Poverty, early childhood education, and academic competence: the Abecedarian experiment. In: Houston AC, ed. Children in Poverty. New York: Cambridge University Press, 1991:190-221.

105. Olds DL. The nurse-family partnership: an evidence-based preventive intervention. Infant Ment Health J 2006;27:5-25.

106. Muennig P, Schweinhart L, Montie J, Neidell M. Effects of a prekindergarten educational intervention on adult health: 37-year follow-up results of a randomized controlled trial. Am J Public Health 2009;99: 1431-7.

107. CAP4Kids (The Children's Advocacy Project) http://cap4kids.org/whatiscap4kids.html Reach Out and Read, 2014. (http://www.reachoutandread. $\operatorname{org} /)$.

108.Zero to Three. Infants and Toddlers in Early Head Start, 2009. (http:// www.zerotothree.org/public-policy/policy-toolkit/ehssinglesmar5.pdf.)

109. DeBaun B, Roc M. Saving Futures, Saving Dollars: The Impact of Education on Crime Reduction and Earnings. Washington, DC: Alliance for Excellent Education, 2013.

110. Heckman JJ. Invest in Early Childhood Development: Reduce Deficits, Strengthen the Economy, 2012. (http://heckmanequation.org/ content/resource/invest-early-childhood-development-reduce-deficitsstrengthen-economy.) 
111.Blumenshine P, Egerter S, Barclay CJ, Cubbin C, Braveman PA. Socioeconomic disparities in adverse birth outcomes: a systematic review. Am J Prev Med 2010;39:263-72.

112. Braveman PA, Heck K, Egerter S, et al. The role of socioeconomic factors in Black-White disparities in preterm birth. Am J Public Health 2015;105:694-702.

113. Gilmore JH, Schmitt JE, Knickmeyer RC, et al. Genetic and environmental contributions to neonatal brain structure: a twin study. Hum Brain Mapp 2010;31:1174-82.

114.Krishnadas R, Kim J, McLean J, et al. The envirome and the connectome: exploring the structural noise in the human brain associated with socioeconomic deprivation. Front Hum Neurosci 2013;7:722.

115. Sporns O, Tononi G, Kötter R. The human connectome: a structural description of the human brain. PLoS Comput Biol 2005; $1: \mathrm{e} 42$.

116. Almli CR, Rivkin MJ, McKinstry RC; Brain Development Cooperative Group. The NIH MRI study of normal brain development (Objective-2): newborns, infants, toddlers, and preschoolers. Neuroimage 2007; 35:308-25.

117. Shi F, Yap PT, Wu G, et al. Infant brain atlases from neonates to 1- and 2-year-olds. PLoS One 2011;6:e18746. 